\title{
Tourism Development and Strategy for Increasing Numbers of Visitors in Kediri
}

\author{
Anisah Azizah* \\ Master Program in Urban and Regional Planning, Faculty of Engineering, University of Brawijaya, Malang, Indonesia
}

\begin{abstract}
Tourism is one source of local revenue. The key to improve quality of tourism destination is effective strategy to develop tourism sectors. To develop tourism sector, one should emphasize on adequate maintenance of tourism destination and management. Studies have been conducted in Kediri analyzing how potential the area was for touris $m$ destination. It was expected that number of visitors and local revenue would increase by describing both internal and external factors supporting the tourism sector in the area. The study was a descriptive study that employed mixed methods (quantitative and qualitative). The data analysis methods were SWOT analysis followed by weighing using IFAS-EFAS analysis. The findings were (a) the government of Kediri should build shopping center that highlighted the local wisdom and more shopping centers more particularly in tourist destination that had no "something to buy" yet, (b) launch various tourism programs, (c) spread information about tourism in Kediri more widely, and (d) involve various types of mass media for promoting the tourism spots in Kediri. It was predicted that the strategy of which purpose was improving quality of tourism spot along with the continuous development plan would improve tourism sector in the area. Once targeted number of visitors had been achieved, the local revenue of Kediri would increase simultaneously. Recommendation strategy is Aggressive Maintenance strategy, where institutions or organizations responsible for the tourism destination develop the area actively and aggressively. We recommend the procedures of the Aggressive Maintenance to develop logic and analytical concepts, as well as make analysis and conceptualize short and long-term priorities.
\end{abstract}

Keywords: Kediri, SWOT, Tourism Development.

\section{INTRODUCTION}

Increasing cycle of national development becomes stimulus for various sectors to improve their performance. The cycle has direct influence towards the industry which closely related to increasing quality of management in particular sector. Based on the global economic perspective, there are several sectors that potentially increase local revenue; one of the sectors is tourism. The government should take the growth of tourism sector into account. Tourism is one of the largest industries in the world getting currencies to global economy and creating new job opportunities as well as providing socio-cultural interactions [1]. Therefore, the government, more particularly the local government, as the authority and tourist organizations should establish a synergy in order to overcome issues related to tourism.

There is certain value that involved complex synergy between various components of tourism. Tourism refers to combination of phenomena and relationships as the result of interaction

\footnotetext{
${ }^{*}$ Correspondence address:

Anisah Azizah

Email : Aniizaah12@gmail.com

Address : Faculty of Engineering, Brawijaya University, Mayjen Haryono, 65145 Malang
}

between tourist, business, local government, and locals in carrying out activities of which purpose are to attract or serve visitors [2]. Based on the 2011 Government Regulation No. 50 about the Grand Plan for Developing the National Tourism 2010-2025, tourism refers to any activities related to tourism and is multidimensional and multidisciplinary as the cause of need of individual or a country as well as interaction between tourists and the locals, among tourists, government, local government and business people. All components of tourism sector will have positive overview to achieve substantial value of development. The components would also have positive influence towards all related elements, network of information, coordination between government and society, and development of infrastructure. These elements should be maximized in order to accelerate the national development.

Tourism is considered as potential sector to increase local revenue. Related to that, it is expected that program of which purpose is to develop and utilize local tourism resource as well as potentials will contribute to economic development. Furthermore, tourism development should essentially be inseparable from the quality of tourism destinations or attractions as an important element of tourism. The 
development should maximize the potentials that exist. Destinations are places towards which people travel and where they choose to stay for a certain period [3], and can be recognized as a perceptual concept, interpreted subjectively by visitors, where a combination of all products, services and experiences are provided locally [4]. Tourism is an extremely complex phenomenon, which cuts across many sectors such as transportation, hotels, fresh water supplies, waste management and energy [5]. Thus, tourism destination is potential component everyone should pay attention to in tourist development.

Based on the 2012 Regulation of East Java Government No. 5 article 1, municipality of Kediri is one of the areas that meet the categories for development. Referring to the condition of the area, Kediri is a municipality in East Java with a lot of potentials for tourism but the tourism sector in the area needs some improvement, for example quality of the tourist destination is relatively low and as the effect, the number of visitors is pretty low as well.

Based on the current situation, the area should develop programs to develop its tourism sector that is determining some strategies of which purpose is to develop quality of the tourism destination in the area. There are several things to consider when tourism becomes the start of the local development. Profile of the locals should also be taken into account because the public is the one with direct access and the one to support all aspects of tourism. Using another perspective, tourism planners need to be aware of the demographic profile of residents who are in support of tourism development [6], in order to establish a set of plan that meets the local context. Direct analysis towards development program in which the locals actively participate will result in a synergic pattern for successful tourism development programs. The development programs should analyze internal and external factors supporting tourism sector because the result of the analysis may increase the number of visitors and eventually the local revenue of Kediri.

\section{RESEARCH METHOD}

The study was descriptive study with mixed method (quantitative and qualitative) approach. The data analysis methods were SWOT analysis followed by weighting using Internal Factors Analysis Summary and External Factors Analysis Summary (IFAS-EFAS analysis).

\section{Data Collection}

Data collection technique referred to methods used to obtain relevant data for the study. The instruments for the data collection were questionnaire, field survey and observation. The data collection method should meet the type of data the researcher needed. Table 1 described the type of data and the instruments used.

To determine the sample, the study used non probabilistic sampling technique that was to determine the respondents using Judgement Sampling technique in which the Krejcie table was involved, the level of significance was $95 \%$ and the level of alpha error was 0.05 [7]; the population was $\pm 1,000,000$ and therefore, the total sample was 384 samples. Samples in the study are respondents who travel in tourism destinations, both local and non local tourists.

\section{Data Analysis}

SWOT analysis was one of the strategic planning methods to describe situation and evaluate one issue in the plan based on internal and external factors, namely Strengths, Weakness, Opportunities and Threats (SWOT) [8].

\begin{tabular}{|c|c|c|c|}
\hline No. & Variable & Type of Data & Data Observation Technique \\
\hline 1. & Transportation & $\begin{array}{l}\text { - } \quad \text { Physical condition and road } \\
\text { - } \quad \text { Route } \\
\text { - } \quad \text { Time } \\
\text { - } \quad \text { Means of transportation }\end{array}$ & Field Observation \\
\hline 2. & Tourism Spot & $\begin{array}{l}\text { Potential aspect of tourism to develop } \\
\text { (nature, culture, and special interest) } \\
\text { - Unique aspects and various tourism } \\
\text { attractions being offered } \\
\text { - Popular Tourist destination }\end{array}$ & $\begin{array}{l}\text { Field Observation and } \\
\text { Interview }\end{array}$ \\
\hline 3. & Facility & $\begin{array}{l}\text { - Current condition of infrastructure and } \\
\text { facilities for tourist } \\
\text { - Tourist's perception on the infrastructure } \\
\text { and facilities }\end{array}$ & $\begin{array}{c}\text { Field Observation and } \\
\text { Questionnaire }\end{array}$ \\
\hline
\end{tabular}


Overall, SWOT may be divided into two parts: the first part was SW, mainly used to analyze the internal conditions. The second part was OT, mainly used to analyze the external conditions [9]. SWOT analysis, also known as SWOT matrix, had often been used in field of business and extended to that of natural resource manage-ment in order to assess a given decision, project or policy directive in a systematic manner [10].

In the study, the objective of the SWOT analysis was to identify internal and external factors that had direct influence towards tourism destinations. We analyze opportunity and strength of the area to design plans for the future and overcome weakness and threats with the plans. The method was based on two tiers of analysis which were conducted separately. First step was to analyze the internal factors (local analysis) which contained a discussion on strengths and weaknesses according to the aims of the SWOT. The second step was to analyze the external factors (global analysis) which contained a discussion on relevant opportunities and threats (positive/negative framework conditions, potential chances and risk [11].

In utilizing SWOT, there were some alternatives based on combination of the following aspects, namely:

a. SO strategy, utilizing optimal strength $(S)$ to get opportunity $(\mathrm{O})$

b. WO strategy, minimizing weakness (W) to get opportunity (O)

c. ST strategy, utilizing optimal strength (S) to anticipate or deal with threat $(\mathrm{T})$ and turning threat into opportunity.

d. WT strategy, minimizing weakness (W) to avoid threat $(T)$ better.

The variables involved in the SWOT analysis were ones related to the internal and external factors of the tourism destinations. Tourism destination was frequently referred to as destination mix, which was described with the following elements: attraction, facilities, infrastructure, transportation and hospitality [12]. The tourism destinations were made up of four elements frequently referred to as $4 \mathrm{~A}$ such as access, amenities, attraction, and ancillary [13]. According to the World Tourism Organi-zations [14], there were six elements of tourist destination such as amenity, access, attractions, human resources and price. The three main components of a tourist destination were made up of facilities, infrastructure and tourism destination [15]. Based on the 2011 Government Regulation No. 50, the variables that composed tourist destination were:
a. Tourist Attraction
b. Public Facility
c. Facility for Tourist/ Visitors
d. Accessibility
e. Public Participation

Other components of the data analysis were internal strategic factor (IFAS) and external strategic factor (EFAS). IFAS consisted of strength and weakness while EFAS consisted of opportunity and threat. IFAS-EFAS analysis was development of SWOT matrix analysis. The basic concept of the development and strategy started from determining criteria and weighting of the factors resulting from the SWOT analysis. The result of the weighting was quadrants. The quadrants would determine development plan of the weighting sectors.

IFAS-EFAS was determined by evaluating all aspects of SWOT (internal and external factors) related to the 5 variables mentioned previously and giving score between 0.00 and 1.00 . The total weighting of all the factors would result in 1 . The following step was multiplying the weighting of all of the factors and the rating that had been designed previously, and the total would determine $X$ and $Y$ factors. The researcher then calculated $X$ (strengthweakness) and $Y$ (opportunity-threat) factors and put the result into the IFAS-EFAS quadrant in order to describe direction for the strategies.

\section{RESULT AND DISCUSSION SWOT Analysis}

The SWOT analysis for the tourism destination in Kediri showed in Table 2. We developed an alternative by combining each of the aspects with SWOT strategy matrix as follow:

- Strategy that correlated Strength and Opportunity, exploring the cultural heritage, natural resources, and elevating available tourism attractions

Strategy that correlated Strength and Threat, more exploration towards the tourism attractions thus they had competitive advantages and able to compete against other tourism attractions in other areas

- Strategy that correlated Weakness and Opportunity, improving quality and quantity of tourist facilities and building, e.g. shopping centers especially in cultural tourism destinations that seemed to attract more visitors. 
Table 2. SWOT Analysis on Tourism in Kediri

\begin{tabular}{llcc}
\hline \multicolumn{2}{c}{ Internal Factor } & \multicolumn{1}{c}{ Weakness } & External Factor \\
\hline - Various type of tourism destination & - Lack of shopping center and & - More visitors visit the & - Similar tourism \\
(nature, culture, and man-made) & local souvenirs in nearly all & cultural tourism & destinations \\
- Scenic nature (mountain and & tourism destinations in the & destinations & nearby \\
waterfall) & area & - Visitors respond the & - Lack of public \\
- Several cultural heritage & - Limited number of industry & natural and cultural & participation in \\
- Well-known souvenirs (tofu and & highlighting the local wisdom & tourism destination \\
handicraft) & of Kediri & positively resulting in \\
- Friendly locals and safe & - Lack of information center & non-direct promotion. \\
environment & and means of promotion the & - Lack of investors \\
- Simpang Lima Gumul as the & - No tourist program available & preservation \\
landmark of Kediri as well as Kediri & - Most of the roads to the & - Various cultural \\
Lagi slogan representing the & tourism destination are in & attractions for visitors to \\
landmark & poor condition & select
\end{tabular}

Source: Data Analysis, 2016

- Strategy that correlated Weakness and Threat, increasing information and promotion about tourism destination in the area and inviting the public to take active participation in developing the tourism destination in the area.

\section{IFAS-EFAS Matrix}

In order to obtain the score of each of the factors, IFAS-EFAS analysis was conducted to determine criteria and weighting in each of the factors and those that became the result of the SWOT analysis. The steps of the IFAS-EFAS analysis were weighting the factors after the SWOT analysis was conducted. Having finished the weighting, the researchers rated the aspects indicating their levels of importance. The rating should meet the criteria decided previously. The rating in the IFAS-EFAS analysis for the tourism sector in Kediri was determined by the following assumptions:

- Criteria 1 was rated 1 (low)

- Criteria 2 was rated 2 (fair)

- Criteria 3 was rated 3 (high)

Based on Table 3, the total weighting was multiplied by rating represent how the tourism destination reacted to their internal strategic factors. The scores for Strength and Weakness were 1.119 and 1.500 respectively; the weakness score was higher than that of strength. Therefore, the first step in the development program was to solve and prevent the internal problems in the tourism sector of Kediri since the factors had significant influence towards tourism development in the area. Once the issues had been identified and solved, the development plan would run smoothly.

Table 3. IFAS Analysis

\begin{tabular}{|c|c|c|c|c|c|c|c|}
\hline Strength & $\begin{array}{l}\text { Score } \\
\text { (b) }\end{array}$ & $\begin{array}{l}\text { Rate } \\
\text { (r) }\end{array}$ & b X r & Weakness & $\begin{array}{l}\text { Score } \\
\text { (b) }\end{array}$ & $\begin{array}{l}\text { Rate } \\
\text { (r) }\end{array}$ & b X r \\
\hline $\begin{array}{l}\text { Various type of tourist } \\
\text { destination (nature, culture, } \\
\text { and man-made) }\end{array}$ & 0.119 & 3 & 0.357 & $\begin{array}{l}\text { Lack of shopping center and } \\
\text { local souvenirs in nearly all } \\
\text { tourist destinations in the area }\end{array}$ & 0.095 & 3 & 0.286 \\
\hline $\begin{array}{l}\text { Scenic nature (mountain and } \\
\text { waterfall) }\end{array}$ & 0.095 & 2 & 0.190 & $\begin{array}{l}\text { Limited number of industry } \\
\text { highlighting the local wisdom } \\
\text { of Kediri }\end{array}$ & 0.048 & 3 & 0.143 \\
\hline Several cultural heritage & 0.071 & 2 & 0.143 & $\begin{array}{l}\text { Lack of information center and } \\
\text { means of promotion }\end{array}$ & 0.119 & 3 & 0.357 \\
\hline $\begin{array}{l}\text { Well-known souvenirs (tofu and } \\
\text { handicraft) }\end{array}$ & 0.024 & 2 & 0.048 & No tourist program available & 0.024 & 3 & 0.071 \\
\hline $\begin{array}{l}\text { Friendly locals and safe } \\
\text { environment }\end{array}$ & 0.048 & 2 & 0.095 & $\begin{array}{l}\text { Most of the roads to the } \\
\text { tourist destination are in poor } \\
\text { condition }\end{array}$ & 0.071 & 3 & 0.214 \\
\hline $\begin{array}{l}\text { Simpang Lima Gumul as the } \\
\text { landmark of Kediri as well as } \\
\text { Kediri Lagi slogan representing } \\
\text { the landmark }\end{array}$ & 0.143 & 2 & 0.286 & $\begin{array}{l}\text { Traffic signs are in poor } \\
\text { condition }\end{array}$ & 0.143 & 3 & 0.429 \\
\hline TOTAL & 0.500 & 13 & 1.119 & TOTAL & 0.500 & 18 & 1.500 \\
\hline
\end{tabular}


Table 4. EFAS Analysis

\begin{tabular}{|c|c|c|c|c|c|c|c|}
\hline Opportunity & $\begin{array}{c}\text { Score } \\
\text { (b) }\end{array}$ & $\begin{array}{l}\text { Rate } \\
(r)\end{array}$ & $\mathbf{b} \mathbf{X r}$ & Threat & $\begin{array}{c}\text { Score } \\
\text { (b) }\end{array}$ & $\begin{array}{l}\text { Rate } \\
\text { (r) }\end{array}$ & $\mathbf{b} \times \mathbf{r}$ \\
\hline $\begin{array}{l}\text { More visitors visit the cultural tourist } \\
\text { destinations }\end{array}$ & 0.207 & 3 & 0.621 & $\begin{array}{l}\text { Similar tourist destinations } \\
\text { nearby }\end{array}$ & 0.103 & 2 & 0.207 \\
\hline $\begin{array}{l}\text { Visitors respond the natural and cultural } \\
\text { tourist destination positively resulting in } \\
\text { non-direct promotion }\end{array}$ & 0.069 & 3 & 0.207 & $\begin{array}{l}\text { Lack of public participation } \\
\text { in developing the local } \\
\text { tourism }\end{array}$ & 0.155 & 2 & 0.310 \\
\hline Potentials for cultural preservation & 0.138 & 2 & 0.276 & \multirow[b]{2}{*}{ Lack of investor } & \multirow[b]{2}{*}{0.052} & \multirow[b]{2}{*}{2} & \multirow[b]{2}{*}{0.103} \\
\hline $\begin{array}{l}\text { Various cultural attractions for visitors to } \\
\text { select }\end{array}$ & 0.276 & 3 & 0.828 & & & & \\
\hline $\begin{array}{l}\text { TOTAL } \\
\end{array}$ & 0.690 & 11 & 1.931 & TOTAL & 0.310 & 6 & 0.621 \\
\hline
\end{tabular}

Based on the EFAS analysis (Table 4) the result of the multiplication of weighting and rating of Opportunity was higher than that of Threat. In other words, opportunity had more significant influence towards the tourist development strategy for the tourism sector in Kediri. Therefore, the opportunity related to the tourism in Kediri should be explored optimally because it would improve the quality of the tourist destination in the area.

Based on the result of the IFAS-EFAS analysis, the following equation was used to determine $X$ and $Y$ factors that became the inputs in the strategic matrix (Fig. 1). The equation was as follow:

$$
\begin{aligned}
\mathrm{X} & =\text { Strength }- \text { Weakness } \\
& =-0.381 \\
\mathrm{Y} & =\text { Opportunity }- \text { Threat } \\
& =1.31
\end{aligned}
$$

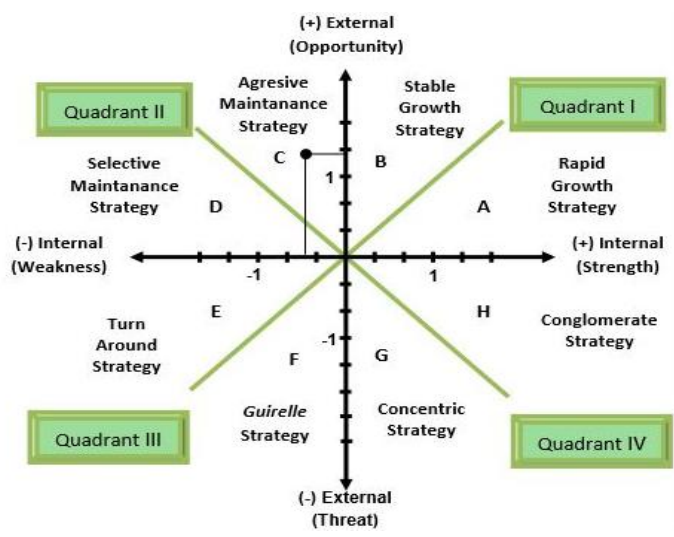

Figure 1. IFAS EFAS Matrix (Source: Data Analysis, 2016)

Having finished the SWOT analysis towards the variables related to the tourism sector in Kediri, the researchers conducted weighting and IFAS-EFAS analysis of which purpose was to create quadrant. Based on the previous analyses, the meeting point was on quadrant II area $C$. Therefore, the most suitable strategy to develop the tourism in Kediri was Aggressive Maintenance strategy, where institutions or organizations responsible for the tourist destination develop the area actively and aggressively.

\section{Aggressive Maintenance Strategy}

The procedures of the Aggressive Maintenance are developing logic and analytical concepts, as well as making analysis and conceptualizing short and long-term priorities as guidelines for designing steps, actions, tips and tactics. Thus the development programs for tourism would meet the purpose, target and output that had been set previously. The strategy being developed focused on solving challenge and issues related to developing the quality of the tourist destination in Kediri. Therefore, several strategies that would improve the tourism sector in Kediri were as follow:

- Build shopping center that highlighted the local wisdom and more shopping centers more particularly in tourism destination that had no "something to buy" yet

- Launching various tourism programs for visitors to select

Distribute information about tourism in Kediri more widely, including having more traffic signs, involving various types of mass media for promoting the tourism spots in Kediri and improving the tourist facilities such as means of transportation and accommodation.

Strategy for tourism development in Kediri is in form of repair and development of facility. As key priorities in tourism development strategy are formulated to: Improve public facilities, Optimize road condition for better access, Develop more restaurants and accommodations, and Develop souvenir shops [16]. It can be concluded that the existing facilities in tourist destinations is an important component in process of developing tourism destinations.

Aggressive Maintenance strategy expected improvement in terms of quality of the tourism 
destination in Kediri. As the result, the number of visitors and the local revenue would increase.

\section{CONCLUSION}

Aggressive Maintenance is the strategy used in developing the tourism sector in Kediri. It refers to a strategy where institution or organization responsible for tourist destination actively and aggressively develops the tourism destination. The strategy focuses on solving issues or challenge related to the program of which objective is increasing quality of the tourist destination in Kediri.

The Aggressive Maintenance strategy represented several components to develop the tourism destination in the area, namely (a) optimizing shopping centers that incorporate the local wisdom and cultural heritage of Kediri, (b) launching several tourism programs, (c) optimizing public relation staffs to promote the tourism destination, and (d) maximizing selling point of the tourism destination which is systematically run through relevant marketing strategy.

It is pivotal to revisit various technical strategies in managing local tourism destination. The study functions as stimulus for tourism sector in other areas. It is expected that they will increase their management system. The study can further be developed into micro research focusing on smallest part of the substances of tourism. It is expected that other means of analysis give additional value for related studies. Future researchers should conduct studies related to public awareness as the object in synergic management of local tourism. Source of local revenue will be relevant to the vision of the national development of which focus is development of tourism.

\section{ACKNOWLEDGEMENT}

The author would like to particularly to DR. Ir. Surjono, MTP., DR. Ir. Agus Dwi Wicaksono, LRR., and Dr. Septiana Hariyani, ST., MT, for their inputs.

\section{REFERENCES}

[1] Sariisik, M., O. Turkayb and O. Akovac. 2011. How to manage yacht tourism in Turkey: A SWOT analysis and related strategies. Proceeding of International Strategic Management Conference 24, 10141025.

[2] Robert W. M., R. Charles, J. R. Goeldner and R. Brent. 1995. Tourism: principles, practices, philosophies. Wiley. New York.
[3] Leiper, N. 1995. Tourism management. RMIT Press. Melbourne.

[4] Buhalis, D. 2000. Marketing the competitive destination of the future. Tourism Management 21, 97-116.

[5] Xing, Y. and B. Andgerfield. 2011. Modeling the sustainability of mass tourism in island tourist economies. Journal of the Operational Research Society 62, 1742-1752.

[6] Maragh, G. S. 2017. Demographic analysis of residents' support for tourism development in Jamaica. Journal of Destination Marketing and Management 6, 5-12.

[7] Sugiyono. 2003. Statistik untuk penelitian. Alfabeta. Bandung.

[8] Humphrey, Albert. 2005. SWOT Analysis for Management Consulting. SR1 Alumni Newsletter. SRI International.

[9] Zhang, X. M. 2012. Research on the development strategies of rural tourism in Suzhou based on SWOT Analysis. Proceeding of International Conference on Future Energy, Environment, and Materials 16, 1295-1299.

[10] Schmoldt, D., J. Kangas, G. Mendoza and M. Pesonen. 2001. The Analytic Hierarchy Process in natural resource and environmental decision making. Springer. The Netherlands.

[11] Reihanian, A., N. Zalina, E. Kahrom and T.W. Hin. 2012. Sustainable tourism development strategy by SWOT analysis: Boujagh National Park, Iran. Tourism Management Perspective 4, 223-228.

[12] Mill, R. C. and A. M. Morison. 2009. The Tourism System $6^{\text {th }}$ Ed. Kendal hunt. USA.

[13] Cooper, C., J. Fletcher, A. Fyall, D. Gilbert and S. Wanhill. 1993. Tourism Principles and Practice. Pitman Publishing. London.

[14] UNWTO. 2012. World Tourism Barometer Vol. 10. United Nation of World Tourism Organizations. Madrid.

[15] Sudiarta, I. N. and I. W. Suaranda. 2016. Tourism destination planning strategy: analysis and implementation of marketing city tour in Bali. Proceeding of International Conference, Intelligent Planning Towards Smart Cities 227, 664-670.

[16] Timang, V., Antariksa, and D. Ari. 2014. Tourism development strategy of Buntula'bi Balusu Sub-village, North Toraja Regency based on tourist perception. Journal of Indonesian Tourism and Development Studies 2(3), 95-102. 